\title{
Firm Profitability and Capital Structure: An Empirical Study on the Listed It Companies of Bangladesh
}

\author{
G.M. Wali Ullah (Corresponding Author) ${ }^{1}$ and Ashraful Islam ${ }^{2}$ \\ ${ }^{1}$ Lecturer, Department of Finance, School of Business, Independent University, Bangladesh (IUB) \\ Basundhara R/A, Dhaka, Bangladesh, E-mail: wali@iub.edu.bd \\ ${ }^{2}$ Graduate, BBA Program, School of Business, Independent University, Bangladesh (IUB), Basundhara \\ R/A, Dhaka, Bangladesh, E-mail: fishan89@gmail.com
}

\begin{abstract}
Capital structure management is both imperative and fundamental in ensuring sound profitability and sustainable growth of businesses, even more so for IT companies as they constantly deal with technological changes and a dynamic marketplace which has seen a significant growth in the past decade in Bangladesh. Generally, various research has been dedicated in understanding how significantly capital structure determinants effect firm profitability, but research focusing on the IT industry is quite scarce. On this background, the objective of this study is to examine the significance of capital structure determinants on the performance of IT companies in Bangladesh, using the OLS multi-regression model. We have used annual data for the period 2007-2015. The findings of the study indicated that capital structure determinants, namely: size and growth were statistically significant in effecting profitability of IT companies in Bangladesh. Whereas, leverage, short-term-debt to asset ratio, tangibility, current and cash-ratios were not significant in affecting firm performance. It seems other factors may have a significant effect, which leaves room for further research in the future.
\end{abstract}

Keywords: IT Companies, Profitability, Capital Structure Determinants, Bangladesh

\section{Background of the Study}

Capital Structure is imperative in ensuring sound financial management and profitability of a company. Since one of the key responsibilities of financial managers is to maximize shareholders' wealth, finding the right mix of financial instruments to fund the operation of the business is quintessential to enhance its growth and profitability [1]. Weston and Brigham [2] defined capital structure as the permanent financing of the firm represented by long-term debt, preferred stock and net worth. The capital structure of the company is a mix of various financial securities, i.e. issuing of large amount of debt (leverage), arranging lease financing, using warrants, convertible bonds, swaps, equity or a combination of other securities to best fit its financial needs. The objective is to collaborate a mix of instruments with the lowest cost that will maximizes overall market value of the company. Planning a capital structure involves the consideration of shareholders' interests; the risk associated with each funding choice; and the significant effect if would have in appropriating funds for immediate and future projects [3].

Traditionally, financial advisers and experts have constantly argued on how a company's leverage affects the firm value, with numerous findings on both sides of the spectrum [4][5]. Most research [6][7][3][4] focused on all listed companies irrespective of industry and showed the significance of leverage, current ratio, cash ratio, tax rate and size on the performance of firms. However, no one optimal capital structure could be determined, as profitability and capital structure tend to vary for firms: operating in different industry; of variable size; and, operating in diverse economies [7]. 
Even though extensive empirical research has been conducted to study the relationship between capital structure and firm performance, little research has focused on IT industry and even less on Bangladesh. Therefore, the objective of this paper is to examine the capital structure determinants affecting the profitability of IT companies in Bangladesh, by using a sample of five IT companies listed in the Dhaka Stock Exchange for the period 2007-2015. This paper will be using ROA as a proxy for firm profitability and capital structure determinants as independent variables, namely: leverage; short-term debt to asset ratio; size; growth; tangibility; current ratio; and, cash ratio. The paper will provide an insight into which capital structure determinants significantly affect firm profitability and help financial managers in the IT industry of Bangladesh to ascertain a capital structure that will help increase profitability.

\section{Literature Review}

Profitability is defined as the ability of a business to generate profit, i.e. the surplus amount remaining after deducting operating and financial expenses as well as other relevant expenses like tax. Return on Assets (ROA) has been commonly used as a proxy for profitability [1]. Three prominent theories on capital structure are: MM capital structure irrelevance proposition; static trade-off theory; and, pecking order theory. The seminal work by Modigliani and Millar [5] for example, concluded that financial leverage plays no part in affecting the firm's market value. Though it should be noted that MM proposition I and II were based on unrealistic assumptions about the reality, but it did provide researchers with the foundations to delve deep in the matter. Research on firm profitability and capital structure has been conducted thoroughly on developed markets, but very rarely focusing on the IT industry. Rub [15] found that the firm's capital structure has a positive impact on the performance measure of the firm. Research by Sayeed [16] used capital structure determinants, based on prominent theories of capital structure: static trade-off theory and pecking order theory and found that Leverage ratio and total debt-to-market value of the firm were used as independent variables and the results showed that agency costs negatively affects total debt ratios and profitability are irrelevant in determining leverage ratios, while firm size has a positive impact in determining both total and long-term debt ratios. In contrast, various studies showed negative or no relationship between capital structure and firm performance. Ebaid [17] found little or no impact of capital structure on firm performance. Huang [18], found a negative correlation between leverage and performance and Zeitun and Tian [19] found that the firm's capital structure has a significantly negative impact on the firm's performance. Robb and Robinson [20] found a significantly positive relationship between leverage and profitability as the use of debt enhances the firm's market value. Abor [7] and Chandrakumarmangalam and Govindasamy [21] both concluded in their study that leverage is positively related to profitability. Berkibitch and Islrael [22] found that level of debt and ROE is positively related when shareholders have total control over the firm's business and negatively related when debt holders have power to influence the course of the business. Negash [9] and, Phillips and Sipahioglu [23] found a negative relationship between leverage and profitability. Murphy's [224] study reported that high leveraged companies show no general tendency to record high rates of return on common equity. Yoon and Jang [25] concluded in their study on restaurants that restaurant firms having large assets were more profitable than small firms and the sign of financial leverage variable was negative which indicated that firms with higher debt rates were less profitable. Long and Malitz [10] found no relationship between capital structure and profitability. Hall et al. [11] found that profitability is not statistically significant to long-term debt and Amjed [12] reported that total debt as a whole has no association with firm profitability because of the inherited different characteristics of short-term and longterm debt. Firm size is inexorably linked to the outcome of a firm in economics, strategic management, accounting and finance. The paper by Jonsson [27] concludes that temporary divergence of a firm's profit from the market average is quickly corrected through the effects of potential or actual entry and exit of businesses or other competitive forces so that no firm can earn a sustainably higher profit above-average over a prolonged period. 
Large firms have more competitive efficacy when compared to small firms in a competitive market, as they are able to buffer losses through internal resources during sordid economic conditions. Additionally, even if an industry is not undergoing growth and firms are not able to achieve external economies of scale, big firms can still attain internal economies of scale through their sheer size. Large firms are able to seize an opportunity to work in a field which requires high capital rates since they have larger resources, and this situation gives them an opportunity to work in more profitable fields with little competition [28]. Majority of the studies concerning size of the firms and its effect on profitability have found a positive relationship between the two variables. Hall and Weiss [29] found a positive relation between firm size and profitability for Fortune 500 firms. Similarly, study by Fiegenbaum and Karnani [30] found a positive relation between firm size and profitability. As no previous studies were dedicated to studying the impact of capital structure determinants of information technology companies in Bangladesh, this paper explores this spectrum.

\section{Methodology}

This study focuses on evaluating the empirical relationship between firm's profitability and different capital structure determinants. It considered a sample of Dhaka Stock Exchange (DSE) listed IT companies for the time period of 2007 to 2015. For this time period of 9 years, five companies were found. Ordinary Least Squared (OLS) regression model using panel data for these companies were used to test the following core hypothesis:

$\mathrm{H}_{0}$ : Capital structure determinants have no significant relationship with IT company profitability.

$\mathrm{H}_{1}$ : Capital structure determinants have significant relationship with IT company profitability.

\subsection{Regression Model}

Using panel data collected from the annual reports, the following model was developed from previous literature, considering Return on Asset (ROA) as the dependent variable,

$$
R O A=\beta_{0}+\beta_{1}(L E V)+\beta_{2}(S T D A)+\beta_{3}(S I Z E)+\beta_{4}(G R)+\beta_{5}(T A N)+\beta_{6}(C R)+\beta_{7}(C A S H)+\varepsilon
$$

Here,

TABLE I: Identification of Variables

\begin{tabular}{ll}
\hline \hline Symbol & Variable Name \\
\hline ROA & Return on Asset (Dependent Variable) \\
LEV & Leverage Ratio \\
STDA & Short-term Debt to Asset Ratio \\
SIZE & Size of the Company \\
GR & Growth of the Company \\
TAN & Tangibility \\
CR & Current Ratio \\
CASH & Cash Ratio \\
\hline \hline
\end{tabular}

\section{Findings and Analysis}

\subsection{Descriptive Statistics}

Table 2 represents the summary statistics of the variables of this study. Total observations of this study were 40, owing to time period of 9 years and 5 listed information technology companies. Descriptive statistics suggests most companies were not significantly leveraged with the highest leverage ratio being $34.7 \%$. The difference in current ratio and cash ratio shows that even though current ratio is quite high as with the median of $485 \%$ and cash ratio standing meekly at $67.5 \%$, which shows that the companies have high inventory and trade receivables in their current assets, as opposed to cash and cash equivalents. 
TABLE II: Descriptive Statistics

\begin{tabular}{lcccccc}
\hline \hline \multicolumn{1}{c}{ Variables } & Mean & Median & Maximum & Minimum & Range, R & $\begin{array}{c}\text { Standard } \\
\text { Deviation }\end{array}$ \\
\hline Profitability & 0.055977 & 0.055515 & 0.122588 & -0.047217 & 0.169805 & 0.034339 \\
Leverage & 0.135452 & 0.109378 & 0.347424 & 0.018123 & 0.329301 & 0.089379 \\
STDA & 0.130975 & 0.097994 & 0.281994 & 0.018123 & 0.263871 & 0.086853 \\
Size & 19.48084 & 19.28393 & 20.95427 & 18.36124 & 2.593030 & 0.637208 \\
Growth & 18.40814 & 18.20155 & 19.58567 & 17.26847 & 2.317200 & 0.794658 \\
Tangibility & 0.515156 & 0.514852 & 0.747393 & 0.254558 & 0.492835 & 0.105529 \\
Current Ratio & 6.533724 & 4.848967 & 20.49272 & 1.469296 & 19.023424 & 5.413397 \\
Cash Ratio & 1.472908 & 0.674812 & 8.034918 & 0.001384 & 8.033534 & 2.086314 \\
\hline \hline
\end{tabular}

\subsection{Regression}

In the OLS regression model, ROA is regressed against all the dependent variables. Table 3 represents the outputs of the regression, with $10 \%$ level of significance.

TABLE III: Regression Estimates (The p-values with * denotes significance in 10\% level.)

\begin{tabular}{ccc}
\hline Variable & Coefficient & Prob. \\
\hline$\beta_{0}$ & 0.142419 & 0.406687 \\
LEV & 0.392781 & 0.275373 \\
STDA & -0.584687 & 0.107720 \\
SIZE & -0.043513 & $0.009975^{*}$ \\
GR & 0.041740 & $0.000875^{*}$ \\
TAN & 0.008902 & 0.854821 \\
CR & 0.002113 & 0.151765 \\
CASH & -0.001453 & 0.602887 \\
\hline R-squared & 0.537200 & \\
Adjusted R-squared & 0.435963 & \\
Prob.(F-statistic) & 0.000424 & \\
\hline \hline
\end{tabular}

\subsection{Discussion of the Findings}

The hypothesis test, summarized in Table 3, reveals that only size and growth of the firm have a significant relationship with the profitability of IT firms, which is consistent with the findings of Hall and Weiss [29], Serrasqueiro and Nunes [31], Lee [32], and Stierwald [33] that have all concluded that size of the firm is significantly positively related to the profitability of firms. However, it contradicts with the findings of Khatab et al. [34] whose findings have shown an insignificant relation between profitability and firm size. Positive relation between growth and profitability found in this study is consistent with studies by: Chowdhury and Chowdhury [4]; Hasan et al. [13]; Zeiun and Tian [19]; and, Sharma and Handoo [35].

Leverage and cash ratio are all found to be not significant in effecting profitability of IT companies in Bangladesh. The results are consistent with the findings of: Long and Malitz [10], and Hall et al. [29] for 
leverage; and, Khidmat and Rehman [36] for cash ratio. Also, Short-term debt to assets, tangibility and current ratio were insignificant in affecting the profitability of IT companies in Bangladesh. However, these findings were inconsistent with previous literature, but as explained earlier, effect of capital structure determinants on profitability varies for companies operating in different industries and economic regions. For IT companies in Bangladesh only size and growth significantly affect profitability.

\section{Summary \& Conclusion}

The capital structure decision is crucial for a business and any strategic decision made with respect to capital structure can inevitably affect profitability and have repercussions in its ability to deal with its competitive environment. This paper explored the effects of capital structure determinants on the profitability of IT companies in Bangladesh, for the period of 2007-2015. The results revealed significantly positive relation between growth and ROA, and a significant negative relation between size of the firm and ROA. Leverage, tangibility, and current ratio were found to be positively related to ROA, but were insignificant factors in affecting profitability. Whereas, short-term debt to assets and cash ratio were found to be negatively related to profitability, but were also insignificant in affecting ROA.

Various research has been devoted in the past on developed markets [5][8][11][23][32][26] to study the impact of capital structure on profitability from diverse industries and regions. Several other papers have also been published to study the same impact for Bangladeshi companies [4][16][13][14], but no literature is available that studied the impact of capital structure determinants on profitability for IT companies, therefore, this research can be vital in providing an insight into the matter. However, the limitations of this paper must not be overlooked. Inclusion of more variables and broadening the sample size can help expand this study and enrich the literature for future researchers.

\section{Reference}

[1] Ross, S. A., Westerfield R. W., \& Jaffe, J. (2010) Corporate Finance. 9th ed. New York, NY: McGraw-Hill/Irwin

[2] Weston, J.F., \& Brigham (1979) Managerial Finance. 2nd ed. USA: Thomson Southwestern

[3] Salawu, R. O. \& Awolowo, O. (2009) The Effect of Capital Structure on Profitability: An Empirical Analysis of Listed Firms in Nigeria. The International Journal of Business and Finance Research, 3(2) pp. 121-129

[4] Chowdhury, A. \& Chowdhury S. P. (2010) Impact of Capital Structure on firm's value: Evidence from Bangladesh. Business and Economic Horizons 3(3) pp. 111-122

[5] Modigliani, F. \& Miller, M. (1958) The cost of capital, corporate finance and the theory of investment. American Economic Review, 48, pp. 261-97

[6] Bauer, P. (2004) Determinants of Capital Structure: Empirical Evidence from the Czech Republic. Czech Journal of Economics and Finance, 55, pp. 2-21

[7] Abor, J. (2005) The Effect of Capital Structure on Profitability: An Empirical Analysis of Listed Firms in Ghana. The Journal of Risk Finance, 6(5) pp. 438-445

[8] Myers, S.C. \& Majluf, N.S., (1984) Corporate Financing and Investment Decisions when Firms have information that Investors do not have. Journal of Financial Economics, 13, pp. 187-221

[9] Negash, M. (2001) Debt, Tax Shield and Bankruptcy Costs: Some Evidence from Johannesburg Stock Exchange. Investment Analysis Journal, 54(3), pp. 114-128

[10] Long, M. \& Malitz, I. (1986) The Investment Financing Nexus: Some Empirical Evidence. Midland Corporate Finance Journal. 3

[11] Hall, G., Hutchison, P. \& Michael, M. (2000) Industry Effects on the Determinants of Unquoted SME Capital Structure. International Journal of the Economics of Business, 7(3), pp. 297-312

[12] Amjed, S. (2007) The Impact of Financial Structure on Profitability: Study of Pakistan's Textile Sector. Management of International Business and Economic Systems, pp.440-450 
[13] Hasan, M.B., Ahsan, A.F.M.M., Rahaman, M.A., \& Alam, M.N. (2014) Influence of Capital Structure on Firm Performance: Evidence from Bangladesh. International Journal of Business Management, 9(5), pp. 184-194

[14] Rouf, M.A. (2015) Capital Structure and Firm Performance of Listed Non-Financial Companies in Bangladesh. International Journal of Applied Economics and Finance, 9(1), pp. 25-32

[15] Rub, N.A. (2012) Capital structure and firm performance: Evidence from Palestine Stock Exchange. Journal of Money Investment Bank, 23, pp. 109-116

[16] Sayeed, M.A., (2011) The determinants of selected Bangladeshi listed companies. International Review of Business Research Papers, 7, pp. 21-36

[17] Ebaid, E.I. (2009) The Impact of capital structure choice on firm performance: Empirical evidence from Egypt. Journal of Risk Finance, 10, pp. 477-487

[18] Huang, G. \& Song, F.M. (2006) The determinants of capital structure: Evidence from China. China Economic Review, 17, pp.14-36

[19] Zeitun, R. \& Tian, G.G. (2007) Capital Structure and corporate performance: Evidence from Jordan. Australasian Accounting Business and Finance Journal, 1(4) pp. 40-61

[20] Robb, A. \& Robinson, D.T. (2009) The capital decision of new firms. Institute of Financial Research, 88

[21] Chandrakumarmangalam, S. \& Govindasamy, P. (2010) Leverage- an analysis and its impact on Profitability with Reference to Selected Cement Companies in India. European Journal of Economics, Finance and Administrative Sciences, 27, pp. 1450-2275

[22] Berkivitch, E. \& Israel, R. (1996) The Design of Internal Control and Capital Structure. Review of Financial Study, 9(1), pp. 116-129

[23] Phillips, P.A. \& Sipahioglu, M.A. (2004) Performance Implications of Capital Structure: Evidence from Quoted U.K. Organizations with Hotel Interests. The Services Industry Journal, 24(5), pp. 1-21

[24] Murphy, Jr., J.E. (1968) Effect of Leverage on Profitability, Growth and Market Valuation of Common Stock. Financial Analysts Journal, 24(4), pp. 121-123

[25] Yoon, E. \& Jang, S.C. (2005) The Effect of Financial Leverage on Profitability and Risk of Restaurant Firms. Journal of Hospitality Financial Management. 13(1), pp. 1-18

[26] Gill, Amarjit, Nahum, B. Neil \& Mathur (2011) The effect of capital structure on profitability: Evidence from the United States. International Journal of Management, 28(4), pp. 3-15

[27] Jonsson, B. (2007) Does the size matter? The Relationship Between Size And Profitability Of Icelandic Firms. Bifrost Journal of Social Sciences, 1, pp. 43-55.

[28] Mankiw, N.G. (2012) Principles of Microeconomics. 4th ed. USA: Thompson South-Western

[29] Hall, M. \& Weiss, L. (1967) Firm Size and Profitability. The Review of Economics and Statistics, 49(3), pp.319-331

[30] Fiegenbaum, A. \& Karnani, A. (1991) Output Flexibility - A Competitive Advantage for Small Firms. Strategic Management Journal, 12, pp. 101-114

[31] Serrasqueiro, Z.S. \& Nunes, P.M. (2008) Performance and Size: Empirical Evidence from Portuguese SMEs. Small Business Economics, 31(2), pp.195 - 217

[32] Lee, J. (2009) Does Size Matter in Firm Performance? Evidence from US Public Firms. International Journal of the Economics of Business, 16(2), pp. 189-203

[33] Stierwald, A. (2009) Determinants of Firm Profitability - The Effect of Productivity and its Persistence. Melbourne Institute of Applied Economic and Social Research.

[34] Khatab, H. Masood, M. Zaman, K. Saleem, S. \& Saeed, B. (2011) Corporate Governance and Firm Performance: A Case Study of Karachi Stock Market. International Journal of Trade, 2(1), pp. 40-43

[35] Sharma, K \& Handoo, A. (2014) A study on determinants of capital structure in India. IIMB Management Review, 26, pp. 170-182

[36] Khidmat, W. B., \& Rehman, M. U. (2014) Impact of liquidity and solvency on profitability chemical sector of Pakistan. Economics Management Innovation, 6, pp. 3-13 